\title{
CORRELATION BETWEEN DIAMETER OF MICROORGANISMS AND EFFICIENCY OF MICROORGANISMS DESTRUCTION UNDER GAS/CAVITATION CONDITIONS
}

\author{
Iryna Koval ${ }^{1, \otimes}$
}

https://doi.org/10.23939/chcht15.01.098

\begin{abstract}
The values of effective rate constants of microorganisms destruction $\left(k_{d}\right)$ were compared, depending on the diameter of cells and gas nature bubbling under cavitation conditions. The efficiency of cell destruction under $\mathrm{Ar} / \mathrm{US}$ is larger by 2-2.5 times compared to $\mathrm{He} / \mathrm{US}$, $\mathrm{O}_{2} / \mathrm{US}$ and $\mathrm{CO}_{2} / \mathrm{US}$. Yeast cells were destroyed faster than bacteria $\left(k_{d \text { (veast cells) }}>>k_{d \text { (bacteria cells })}\right)$ that is explained by the cells size. The cell stability under cavitational conditions is reversely proportional to the cell diameter. Considering the cell sizes, the presented dependencies of $k_{d}=f\left(d_{\text {cells }}\right)$ can be successfully used as a standard not only for qualitative determination, but also for evaluating the efficiency of cavitation treatment of water in the presence of $\mathrm{O}_{2}, \mathrm{CO}_{2}, \mathrm{Ar}$ and He.
\end{abstract}

Keywords: cells diameter, cavitation, gas, water, microorganism, destruction.

\section{Introduction}

Hydrosphere pollution is the result of anthropogenic human activity, which is directly dependent on the development of various industries and agriculture. The entry into the water bodies of untreated or insufficiently treated wastewater (WW) of chemical and food enterprises, urban sewers, livestock complexes, water and rail transport (Dnipro, Siverskyi Donets, the Black Sea near Odessa, etc.) are the main sources of pollution and deterioration of their quality. More than $60 \%$ of untreated WW fall into open reservoirs, the remaining $40 \%$ goes without treatment. This leads to a complex environmental state of the environment, a decrease in clean drinking water resources, poses a serious risk to public health in many regions of Ukraine, causes a high incidence of intestinal infections, hepatitis, increases the risk of exposure to human carcinogenic and mutagenic factors. The World Health Organization (WHO) reports that the

\footnotetext{
${ }^{1}$ Lviv Polytechnic National University,

12, Bandera St., 79013 Lviv, Ukraine

irynazk@gmail.com

(c) Koval I., 2021
}

annual increase in industrial and agricultural water demand is $4 \%$ and doubles every 20 years.

According to [1], in 1994, urban sewage systems dumped more than 1.5 billion $\mathrm{m}^{3}$ of polluted $\mathrm{WW}$ into natural reservoirs annually. Reduction of man-made load and volumes of water use did not lead to improvement of water quality. In 2006 more than 2 billion $\mathrm{m}^{3} /$ year of WW got into the water objects of Ukraine [2], in $2010-$ approximately 2.6 billion $\mathrm{m}^{3} /$ year of household and industrial WW containing $\sim 8$ million tonnes of different pollutants [3], and in $2018-2.9$ billion $\mathrm{m}^{3}$ of contaminated WW. As we can see, according to the average data, the anthropogenic load of the hydrosphere significantly increases in time in the future.

In assessing the degree of water risk to health, microbial contamination plays a crucial role, depending on the nature of the unwanted impurities in it [4]. Studies have shown that the risk of diseases from microbial contamination of water is much higher (up to 100,000 times) than with water contamination by chemicals of different nature. According to official WHO statistics, pathogens are the cause of dangerous diseases, resulting in 2.2 million people dying annually.

Common methods of water disinfection among many chemical methods are chlorination, ozonation, hydrogen peroxide treatment and others. However, the disadvantages of these methods (formation of disinfection byproducts, low efficiency of the process, the reactivation of MO, the risk of overdose, etc.) significantly limit their use in water cleaning processes. The modern technologies allow disinfection of water without using chemicals. So, more and more importance is attracted to physical factors of influence on a water system, including the use of cavitation water treatment. The advantages of ultrasonic (US) cavitation treatment of water among other methods of water disinfection (exposure to chlorine, chlorinecontaining compounds, ozone and ultraviolet (UV)) are represented in Table 1.

Recently, many works have been devoted to the study of the effect of ultrasound cavitation in the processes of water disinfection from different MO: E. coli 
[5, 6], Staphylococcus aureus [5], Microcystis aeruginosa [7-9], algal bloom [10], Listeria monocytogenes [6], Geobacillus [11], Anoxybacillus flavithermus [11], Enterococcus avium [12]. However, experimental works on the destruction of MO, such as Diplococcus, Sarcina, Bacillus, Pseudomonas fluorescens and Sacch. cerevisiae under cavitation conditions with simultaneous bubbling of gases of different nature were not found.

Table 1

Comparative characteristics of water disinfection methods

\begin{tabular}{|c|c|c|c|c|c|c|}
\hline \multicolumn{7}{|c|}{ Methods of water disinfection } \\
\hline Name & chlorine & $\begin{array}{c}\text { sodium } \\
\text { hypochlorite }\end{array}$ & $\begin{array}{l}\text { chlorine } \\
\text { dioxide }\end{array}$ & ozone & UV & US cavitation \\
\hline \multicolumn{7}{|c|}{ Characteristic features of water disinfection methods } \\
\hline $\begin{array}{l}\text { Effectiveness of most disease- } \\
\text { causing MO }\end{array}$ & + & + & + & + & + & + \\
\hline $\begin{array}{l}\text { Effectiveness of action on all } \\
\text { types of MO }\end{array}$ & - & - & + & + & + & + \\
\hline $\begin{array}{l}\text { Initiation of formation (I) / } \\
\text { absence (II) of by-products of } \\
\text { disinfection }\end{array}$ & (I) - & (I) - & (I) - & (I) - & \pm & (II) + \\
\hline $\begin{array}{l}\text { Dependency (I) / non- } \\
\text { dependence (II) of disinfectant } \\
\text { activity on water quality } \\
\text { (turbidity, hardness, presence } \\
\text { of organic substances, etc.) }\end{array}$ & (I) - & (I) - & (I) - & (I) - & (I) - & (II) + \\
\hline $\begin{array}{l}\text { Removal of foreign odors and } \\
\text { odors from water }\end{array}$ & + & + & + & + & + & + \\
\hline $\begin{array}{l}\text { Termination (I) / non-termina- } \\
\text { tion (II) of growth of aquatic } \\
\text { vegetation and biofouling in } \\
\text { water distribution systems }\end{array}$ & (I) + & + & (I) + & \pm & (II) - & + \\
\hline Prolonged effect & + & \pm & + & \pm & - & \pm \\
\hline Overdose & - & - & - & + & + & + \\
\hline Automation of the process & - & - & - & - & - & + \\
\hline $\begin{array}{l}\text { Need for storage and } \\
\text { transportation of reagents }\end{array}$ & - & \pm & - & - & * & * \\
\hline References & $\begin{array}{l}{[3,4,13,14,} \\
15,16,17,18]\end{array}$ & {$[4,13]$} & {$[4,13]$} & 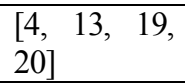 & {$[4,13,21]$} & $\begin{array}{l}{[4,12,13,22,} \\
23,24,25,26]\end{array}$ \\
\hline
\end{tabular}

Note: * absence of this feature.

The effect of cavitation on different types of $\mathrm{MO}$ is different depending on their morphological characteristics, the initial amount per unit volume of water, etc., which indicates the specificity of the impact of the acoustic field on microscopic biological objects. However, there is no experimentally substantiated evidence to support this fact in the literature. Therefore, the studies of this work are aimed at studying the effect of cavitation on the viability of various types of MO in water under the simultaneous action of gas bubbling, taking into account the peculiarities of cell structure.

\section{Experimental}

The source of cavitation was an ultrasonic wave source, namely UZDN-2T generator operating at a frequency of $22 \mathrm{kHz}$ generating $35 \mathrm{~W}$. All experiments were carried out at $T=298 \pm 1 \mathrm{~K}, P=0.1 \mathrm{MPa}, t=2 \mathrm{~h}$; the investigated water volume was $75 \mathrm{~cm}^{3}$. The concentration of microbial cells was determined by the number of colony forming units (CFU), assuming that each colony developed from a single cell. Diplococcus, Pseudomonas fluorescens, Bacillus cereus, Sarcina lutea bacterias and Saccharomyces cerevisiae yeasts were used as microorganisms for investigations.

The essence of the method of determining the number of microorganisms (NM) in $1 \mathrm{~cm}^{3}$ is to determine the total amount of MO capable of growing on meatpeptone agar (MPA) (for bacteria) or wort-agar (WA) (for yeast) on Petri dishes at the temperature of $308 \pm 0.5 \mathrm{~K}$ for $48 \pm 2 \mathrm{~h}$ in $1 \mathrm{~cm}^{3}$ of water, followed by counting colonies grown on a nutrient medium. 
General NM in $1 \mathrm{~cm}^{3}$ of water is determined by the following stages: breeding; sown on a solid nutrient medium in Petri dishes; count of colonies grown on the medium.

For seeding, nutrient media, sterile petri dishes, pipettes, and test tubes must be prepared in advance. Samples were thoroughly mixed before sowing, depending on the imputed contamination, prepared 10fold dilutions in sterile water. A separate pipette was used for each dilution and was sequenced sequentially from the largest dilution to the smallest.

In the study of water samples it is necessary to dilute it before sowing, based on the estimated amount of MO in $1 \mathrm{~cm}^{3}$. Since water was used for research from the open reservoir with the addition of specific MO, so three dilutions were prepared.

Empty sterile tubes (one for each water sample), tubes with $9 \mathrm{~cm}^{3}$ of sterile water (for dilution) and sterile pipettes were pre-prepared. A sample of investigated water $\left(10 \mathrm{~cm}^{3}\right)$ was transferred to an empty sterile tube, denoted as " 0 " (without dilution), from which $1 \mathrm{~cm}^{3}$ of water was then introduced into a dilution tube by sterile pipette. The tube was closed with a cotton plug, mixed well, and thus the first dilution (1:10) was obtained. The suspension obtained in the first dilution was mixed thoroughly. $1 \mathrm{~cm}^{3}$ of dilution was then transferred by a sterile pipette to the second tube with $9 \mathrm{~cm}^{3}$ of sterile water; thus the second dilution (1:100) was obtained, and so on. The number of dilutions was prepared depending on NM in the investigated water.

Each dilution was sown in at least three parallel Petri dishes by the deep method as follows: a seeding dose $\left(1 \mathrm{~cm}^{3}\right.$ of water) of appropriate dilution, starting with the largest, was introduced with a sterile pipette in a sterile, slightly open Petri dish in accordance with the rules of sterility. The dose was immediately poured by $15-20 \mathrm{~cm}^{3}$ of molten and cooled to 318-321 K nutrient medium. The lid of the Petri dish was closed and the light rotating movements of the cup carefully mixed the nutrient medium with the seed to cover the bottom evenly. To check the sterility of the nutrient medium MPA or WA without water was injected in one of Petri dishes. The Petri dishes were left in a horizontal position to solidify the agar, with MO cells fixed at a certain point in the environment. Then the dishes were turned upside down and transferred to a thermostat with a temperature favorable for growing MO: for bacteria $-310 \mathrm{~K}$, for yeast $-300-303 \mathrm{~K}$. MO cells multiplied and their mass grew to form colonies visible to the naked eye.

Different MO groups grow at different rates, so colonies of bacteria were kept in a thermostat at $T=308 \mathrm{~K}$ for 2-3 days, and yeast - at $T=303 \mathrm{~K}$ for $4-5$ days.
For the quantitative determination of $\mathrm{MO}$, the colonies grown on Petri dishes were counted based on the fact that each colony was evolved from a single cell.

The results obtained were converted to the initial water sample, taking into account the dilution according to the formula (1):

$$
X=a \cdot 10^{n}
$$

where $a$ is the number of colonies grown in the dish; $n$ is a dilution.

To quickly calculate the total number of colonies $(X)$, we determined their number in $1 \mathrm{~cm}^{2}(m)$, multiplying this number by the area of the Petri dish:

$$
S=\pi \cdot r^{2}
$$

where $r$ is the radius of the dish.

Then:

$$
S=m \cdot \pi \cdot r^{2}
$$

The experimental points in the graphic materials presented below were obtained from arithmetic averages of three to four parallel seeding of water samples.

Effective rate constants of cells destruction $\left(k_{d}\right)$ were calculated after combined action of cavitation and gas influence. Oxygen, carbon dioxide, argon and helium were used as an additional source of bubbles in an aqueous medium and were bubbled during the whole process of cavitation action on the cell in the water medium. The effective rate constants of cells destruction were calculated by a kinetic reaction equation of the first order.

\section{Results and Discussion}

Five monocultures which represent different genera: Diplococcus, Bacillus, Sarcina, Pseudomonas and Saccharomyces (Table 2) were used to study gas/ cavitation in water disinfection processes. Thus, in this work we consider a diverse range of microbiological objects.

Model waters were created with the purpose of approximation in terms of qualitative and quantitative composition to the real level of microbiological contamination of industrial WW $\left(\mathrm{NM}_{0}=10^{3}-10^{4} \mathrm{CFU} / \mathrm{cm}^{3}\right)$. The studied MO belong to different groups: spherical (Diplococcus, Sarcina), rod-shaped (Bacillus, Pseudomonas) bacterial forms and oval yeast fungi (Saccharomyces). Objects of the investigated MO include prokaryotes and eukaryotes. The choice of prokaryotes (Sarcina, Diplococcus, Bacillus, Pseudomonas) is related to their physiological diversity, simplicity of cell building, significant growth rate. Saccharomyces yeast was selected as eukaryotic species, because the yeast of this type is isolated from WW brewing. 
Table 2

\section{Characteristics of the studied MO}

\begin{tabular}{|c|l|}
\hline \multicolumn{2}{|c|}{ Bacteria } \\
\hline Diplococcus & diplococci, spherical, arranged in pairs, belong to the family Coccaceae. \\
\hline Sarcina lutea & $\begin{array}{l}\text { sarzines, spherical, placed in packages of 8, 16, 32, etc. cocci), non-pathogenic; belong } \\
\text { to the family Coccaceae. }\end{array}$ \\
\hline Bacillus cereus & $\begin{array}{l}\text { bacilli, rod-shaped bacteria, sporogenic (forming endospores), diameter of spores } \\
\text { smaller than cell diameter; belong to the family Bacillaceae. }\end{array}$ \\
\hline Pseudomonas fluorescens & $\begin{array}{l}\text { pseudomonads, rod-like; asporogenic; moving; characteristic monopolar polytrichal } \\
\text { (lofotrichal) type of plaque; belong to the family Pseudomonadaceae. }\end{array}$ \\
\hline \multicolumn{2}{|c|}{ Yeast } \\
\hline Saccharomyces cerevisiae & baker yeast; stationary cells; belong to the family Saccharomycetaceae. \\
\hline
\end{tabular}

Table 3

The values of effective rate constants of cells destruction under gas/US conditions

\begin{tabular}{|c|c|c|c|c|}
\hline \multirow{2}{*}{ Microorganisms } & \multicolumn{4}{|c|}{$k_{d} \cdot 10^{4}, \mathrm{~s}^{-1}$} \\
\cline { 2 - 5 } & $\mathrm{Ar} / \mathrm{US}$ & $\mathrm{He} / \mathrm{US}$ & $\mathrm{CO}_{2} / \mathrm{US}$ & - \\
\hline Diplococcus & $3.25 \pm 0.06$ & $1.72 \pm 0.03$ & - & - \\
\hline Pseudomonas fluorescens & $3.96 \pm 0.02$ & $0.91 \pm 0.20$ & $2.10 \pm 0.15$ & $1.63 \pm 0.05$ \\
\hline Bacillus cereus & $5.02 \pm 0.03$ & $2.89 \pm 0.04$ & $2.51 \pm 0.04$ & $3.11 \pm 0.06$ \\
\hline Sarcina lutea & $5.95 \pm 0.07$ & $3.30 \pm 0.09$ & - & - \\
\hline Saccharomyces cerevisiae & $7.94 \pm 0.09$ & $5.73 \pm 0.08$ & $5.36 \pm 0.03$ & $4.52 \pm 0.01$ \\
\hline
\end{tabular}

In our previous studies [27, 28], during gases bubbling under cavitation conditions the process time of water purification from yeast was found to be shorter in comparison with treatment time of microbial cells $\left(\mathrm{t}_{\mathrm{gas}} / \mathrm{us}=3600 \mathrm{~s}\right.$ against $\left.\mathrm{t}_{\mathrm{gas}} / \mathrm{US}=7200 \mathrm{~s}\right)$. Therefore, to continue previous studies, we will compare the destruction effective rate constants of yeast and bacteria as well.

Calculated values of destruction effective rate constants under gas/US-action after $\mathrm{t}_{\mathrm{gas} / \mathrm{US}}=7200 \mathrm{~s}$ are represented in Table 3. The gas/cavitation action shows different effectiveness in the process of destruction of various bio-objects in the water system, i.e. this indicates the individual impact of cavitation on the MO. As the conditions of all experiments were the same, justification of the cavitation effect on water disinfection from MO of different types should be sought in the gas nature and morphological characteristics of MO.

The dependence of the effective rate constants MO destruction on the size of their cells during $\mathrm{O}_{2} / \mathrm{US}$, $\mathrm{CO}_{2} / \mathrm{US}$ and $\mathrm{He} / \mathrm{US}$ is shown in Fig. 1. In the $k_{d}=f\left(d_{\text {cells }}\right)$ coordinates under the action of gas/US $\left(\mathrm{He}, \mathrm{CO}_{2}, \mathrm{O}_{2}\right)$ we observe the dependences of the growing character with the fluctuations of $k_{d}$ values in close limits. Therefore, the influence of $\mathrm{He} / \mathrm{US}, \mathrm{CO}_{2} / \mathrm{US}$ and $\mathrm{O}_{2} / \mathrm{US}$ can be described by one linear dependence presented in Fig. $2(\Delta)$. Experimental points of $\mathrm{Ar} / \mathrm{US}$-action are superimposed in the same figure, since these $k_{d}$ values are significantly larger than the $k_{d}$ values for the gas/US action $\left(\mathrm{He}, \mathrm{CO}_{2}\right.$, $\mathrm{O}_{2}$ ). We observe that the dependences of $k_{d}$ on the cell diameter for $\mathrm{Ar} / \mathrm{US}$ (Fig. 3, $\square$ ) and $\mathrm{He} / \mathrm{US} ; \mathrm{CO}_{2} / \mathrm{US} ; \mathrm{O}_{2} / \mathrm{US}$
(Fig. 3, $\Delta$ ) are the same in nature, but differ in $k_{d}$ magnitude: $k_{d(\mathrm{Ar} / \mathrm{US})}>k_{d(\mathrm{He} / \mathrm{US} ; \mathrm{CO} 2 / \mathrm{US} ; \mathrm{O} 2 / \mathrm{US})}$ by $2-2.5$ times.

Hence, MO destruction under cavitation action depends on the nature of gas bubbling during the whole process. The highest MO destruction efficiency was found in the case of $\mathrm{Ar} / \mathrm{US}$ treatment, independently on quantitative and qualitative composition MO in the water system.

The gradually increasing nature of the dependencies $k_{d}=f\left(d_{\text {cells }}\right)$ allows to make conclusion of the effect of the MO morphological characteristics on the efficiency of their destruction in the water system. Therefore, the dependences of the destruction effective rate constants of Diplococcus, S.lutea, B.cereus, Ps.fluorescens bacteria and Sacch.cerevisiae yeast are summarized in Fig. 3 with the exact location of the studied MO by the size of their cells under gas/UStreatment. It is shown that the cells with larger size are easily tending to destruction by gas/US treatment, i.e. the cell stability in cavitational conditions is reversely proportional to the cell size. The $k_{d}$ values for the yeast are higher in few times than those for bacteria cells: $k_{d \text { (yeast cells) }} \gg k_{d \text { (bacteria cells). }}$.

This explains almost complete water refinement from the yeast for a shorter process time comparing with bacteria (yeast cell size is almost 10 times larger than bacteria). That is why among spherical shapes of MO, the most effective destruction is observed for Sarcina, comparing with Diplococcus, as the size of Sarcina differs approximately by 3.5 times (2.2 micrometers for Sarcina bacteria type and 0.6 micrometers for Diplococcus bacteria type). Similar behavior is observed for rodshaped bacteria: Bacillus and Pseudomonas. 


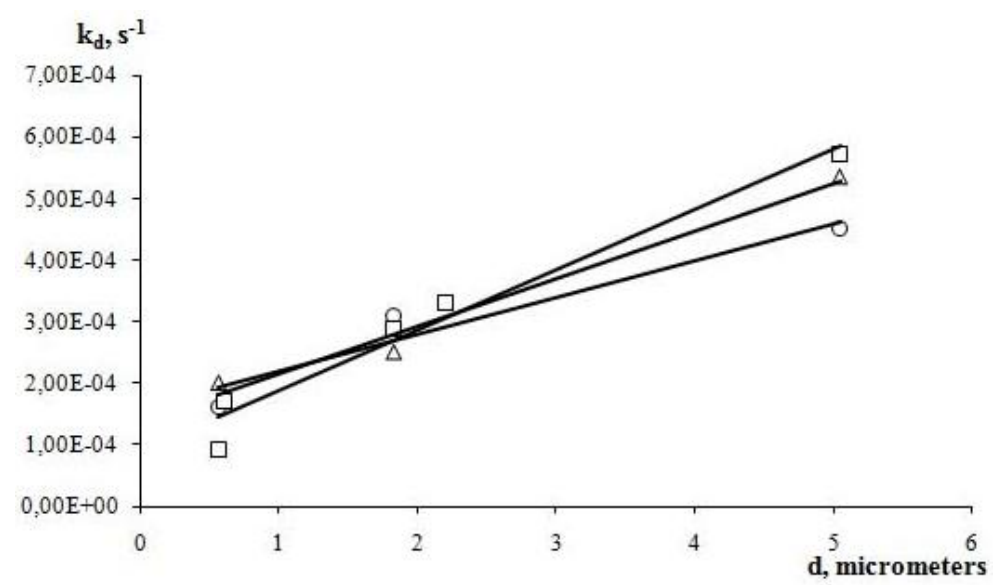

Fig. 1. Dependencies of destruction effective rate constants on MO cells size in the process of gas/US-treatment: $\mathrm{He} / \mathrm{US}(\square), \mathrm{O}_{2} / \mathrm{US}(\Delta), \mathrm{CO}_{2} / \mathrm{US}(\circ)$

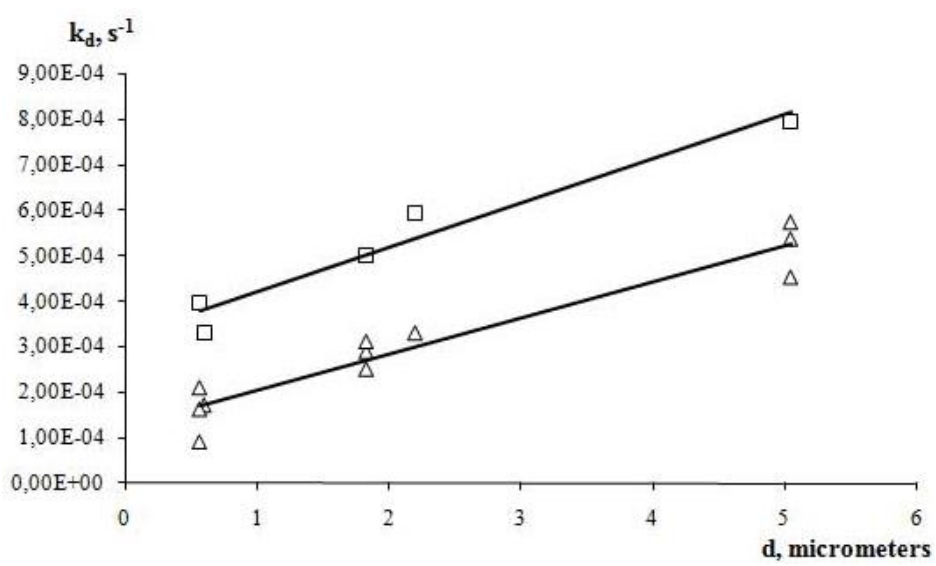

Fig. 2. Dependencies of destruction effective rate constants on MO cells size with a visual expression of the most efficient nature of gas in the process of gas/US-treatment: $\mathrm{Ar} / \mathrm{US}(\square), \mathrm{He} / \mathrm{US}, \mathrm{O}_{2} / \mathrm{US}$ and $\mathrm{CO}_{2} / \mathrm{US}(\Delta)$

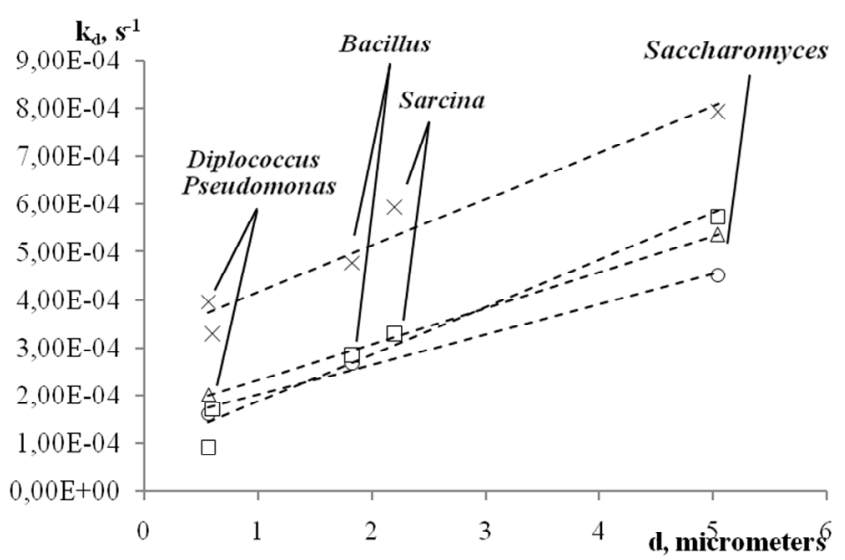

Fig. 3. Generalized dependencies of the destruction effective rate constants of Diplococcus, S.lutea, B.cereus, Ps.fluorescens bacteria and Sacch.cerevisiae yeast with the exact arrangement of the $\mathrm{MO}$ according to the size of their cells in the process of gas/US-treatment: $\mathrm{Ar} / \mathrm{US}(\mathrm{x}), \mathrm{He} / \mathrm{US}(\square), \mathrm{O}_{2} / \mathrm{US}(\Delta), \mathrm{CO}_{2} / \mathrm{US}(\circ)$ 
The experimentally determied series of effective destruction of investigated MO under gas/US-action is as following:

\section{Sacch. cerevisiae $>$ Sarcina lutea $>$ Bacillus cereus $>$ $>$ Pseudomonas fluorescens $>$ Diplococcus}

It should be noted that the investigated unicellular yeast fungi (eukaryotes), unlike prokaryotes, differ significantly not only in size but also in structure. A yeast cell with a fully formed nucleus and a well-developed vacuolar apparatus, unlike a bacterial one, although is characterized by a stronger shell, differs significantly in cell morphology [29].

Comparing the experimental data, namely: the size of the MO cells and the effective rate constants of the cell destruction under gas/US-action we observed the interdependence between these values for the studied MO. The magnitudes of $k_{d}$ naturally increase with the increase of the cells size (Fig. 3), that is, the correlation between these values is observed. Such a pattern is observed for all the gases under study with the most pronounced effect in the argon atmosphere. That is, Ar/US shows greater efficacy on the studied MO compared to helium, oxygen, and carbon dioxide bubbling.

Thus, the nature of gas, the bubbling of which produced the largest number of destroyed MO cells, is clearly seen in Fig. 2. Fig. 3 shows the direct effect of cell diameter on the activity of $\mathrm{MO}$ destruction, indicating the generic feature of the studied MO. Larger cell sizes are more likely to collapse with the simultaneous use of gas and cavitation, since they are described by larger values of $k_{d}$ (Table 3). The resistance of different types of $\mathrm{MO}$ to the effect of cavitation is explained by the result of the specific effect of ultrasound of cavitation on the walls of their cells and the intergenerational difference in cell wall structures [30].

The above data describe an equivocal gas type effect upon the inactivation of microorganisms in a US field. Taking cell sizes into account, the relationship $k_{d}=$ $=f\left(d_{\text {cells }}\right)$ in Fig. 3 allows to predict close to the exact value of the destruction effective rate constant in the liquid containing microorganisms, which were not evaluated in this study. It also allows to identify the most efficient gas/US needing to be applied. Graphic dependencies show an increase in inactivation with increasing a cell size.

Therefore, the experimental data indicate the specific effect and significant influence of the gas nature on the inactivation of $\mathrm{MO}$ in the presence of cavitation. To understand the effect of gas type upon the disinfection of a water system in cavitation conditions and to explain why the greatest efficiency is experienced for argon as opposed to helium, oxygen and carbon dioxide, it is important to take into account those gas properties, which may effect sonochemical activity.
The heat capacity ratio in a gas bubble affects the amount of released heat and consequently the final temperature produced under adiabatic compression. The sonolitic yield of radicals increases with increasing effective temperature of cavitating bubbles, i.e. with the increase in heat capacity ratio. However, it decreases with the increasing thermal conductivity of the gas. Therefore, the highest temperature that can be achieved in a cavity is dependent upon the ratio $C_{p} / C_{v}$ and the thermal conductivity of the dissolved gas.

Monatomic gases are more effective than diatomic gases because of their greater specific heat ratio $\left(C_{p} / C_{v}=\right.$ $=1.667$ for argon and helium; $C_{p} / C_{v}=1.40$ for oxygen and carbon dioxide). Monatomic gases convert more energy into cavitation compared with diatomic gases. Although the $C_{p} / C_{v}$ ratios for argon and helium are the same, a much greater yield of pyrolysis products was obtained in an argon atmosphere [26, 31, 32], due to the 10 times lower thermal conductivity of argon. So, another parameter affecting cavitation collapse is a gas thermal conductivity. Thermal conductivity also determines temperature within a gas bubble. A gas with the low thermal conductivity reduces heat emission from a cavitation occurance due to adiabatic collapse, and should favour a higher collapse temperature compared to that for a high thermal conductivity gas. Additionally, a gas with a higher thermal conductivity reduces the temperature achieved during a bubble collapse.

Argon differs from helium by a lower ionization potential, which contributes to more intense breakdown of water molecules in a cavity. Moreover, argon also has a lower solubility than helium. The impact of gas solubility on sonochemical activities is described below.

The solubility of a gas in a given liquid is also an important factor. Among investigated gases, $\mathrm{CO}_{2}$ has the highest liquid solubility. The more soluble the gas, the more possible its penetration into a cavitation bubble. Well soluble $\mathrm{CO}_{2}$ reduces the liquid cavitation threshold and leads to a greater quantity of gas penetrated into the cavity. Penetrating dissolved gas affects cavities destruction. With the increasing solubility of a gas in water its concentration in cavity increases but significant gas penetration into a bubble retards its collapse and as a result, reduces sonochemical activity.

Thus, argon has the dominant role in the cell destruction process under cavitation conditions. The obtained data not only allow to evaluate the technological possibilities of infected liquids US treatment, but also allows to choose the optimal mode of operation for a highly efficient water disinfection process. 


\section{Conclusions}

The dependences of the destruction effective rate constants on the size of MO cells were determined. Correlation between the values of dectruction effective rate constants and MO cells size under conditions $\mathrm{Ar} / \mathrm{US}$, $\mathrm{He} / \mathrm{US}, \mathrm{O}_{2} / \mathrm{US}, \mathrm{CO}_{2} / \mathrm{US}$ was observed, namely the increase of $k_{d}$ values is obvious for larger cells: $k_{d \text { (yeast cells) }}>>k_{d \text { (bacteria cells). The MO destruction process }}$ under cavitation action depends on the nature of bubbled gas. The value of $k_{d(\mathrm{Ar} / \mathrm{US})}$ is larger than $k_{d(\mathrm{He} / \mathrm{US} ; \mathrm{CO} / \mathrm{US} ; \mathrm{O} 2 / \mathrm{US})}$ by $2-2.5$ times; it means that the highest effectivity of cells destruction was observed under Ar/US conditions regardless the cells size. The cells with larger size were more disposed to destruction by gas/US treatment. A series of MO effective destruction under gas/US was established. The dependences of the destruction effective rate constants on the MO cell diameters allow to apply gas/US results for other varieties of MO. The role of the individual effect of each studied gases under cavitation conditions in the aqueous medium was explained.

\section{References}

[1] Sidenko T.: Vodopostachannya ta Vodovidvedennya: Anatovanyy Bibliohrafichnyy Pokazhchyk. Naukova biblioteka CHNTU, Chernihiv 2017.

[2] Ayrapetyan T.: Tekhnolohiya Ochystky Promyslovykh Stichnykh Vod.: KHNUMH im. O. M. Beketova, Kharkiv 2017. [3] Zahorodnyuk K.: Vodopostachannya ta Vodovidvedennya, 2010, 2, 36.

[4] Strykalenko T.: Vodopostachannya ta Vodovidvedennya, 2009, 1,35 .

[5] Bhavya M., Umesh Hebbar H.: Ultrasonics Sonochem., 2019, 57, 108. https://doi.org/10.1016/j.ultsonch.2019.05.002

[6] Iorio M., Bevilacqua A., Corbo M. et al.: Ultrasonics Sonochem., 2019, 52, 477.

https://doi.org/10.1016/j.ultsonch.2018.12.026

[7] Kong Y., Peng Y., Zhang Zh. et al.: Ultrasonics Sonochem., 2019, 56, 447. https://doi.org/10.1016/j.ultsonch.2019.04.017

[8] Li Y., Shi X., Zhang Zh. et al.: Ultrasonics Sonochem., 2019, 55, 232. https://doi.org/10.1016/j.ultsonch.2019.01.022

[9] Carrillo-Lopez L., Huerta-Jimenez M., Garcia-Galicia I. et al.: Ultrasonics Sonochem., 2019, 58, 104.

https://doi.org/10.1016/j.ultsonch.2019.05.025

[10] Park J., Son Y., Lee W.: Ultrasonics Sonochem., 2019, 55, 8. https://doi.org/10.1016/j.ultsonch.2019.03.007

[11] Palanisamy N., Seale B., Turner A. et al.: Ultrasonics Sonochem., 2019, 51, 325.

https://doi.org/10.1016/j.ultsonch.2018.09.025

[12] Znak Z., Zin O.: Chem. Chem. Technol., 2017, 11, 517. https://doi.org/10.23939/chcht11.04.517

[13] Zhou X., Li Z., Lan J. et al.: Ultrasonics Sonochem., 2017, 35, 471. https://doi.org/10.1016/j.ultsonch.2016.10.028

[14] Shin G.-A., Sobsey M.: Water Research, 2008, 42, 4562. https://doi.org/10.1016/j.watres.2008.08.001

[15] Fei G., Lizhong Z., Jing W.: Desalination, 2008, 225, 156. https://doi.org/10.1016/j.desal.2007.03.016
[16] Lukyanchuk S.: Environment \& Health, 2009, 3, 31.

[17] Potapchenko N.: Voda i Vodoochystnye Tekhnolohyy, 2013, 1, 70.

[18] Miranda A., Lepretti M., Rizzo L. et al.: Sci. Total Environm., 2016, 554-555, 1. https://doi.org/10.1016/j.scitotenv.2016.02.189

[19] Martinelli M., Giovannangeli F., Rotunno S. et al.: J. Prev. Med. Hyg., 2017, 58, E48.

[20] Zheng J., Su Ch., Zhou J. et al.: Chem. Eng. J., 2017, 317, 309. https://doi.org/10.1016/j.cej.2017.02.076

[21] Zyara A., Torvinen E., Veijalainen A.-M. et al.: Water, 2016, 8, 130. https://doi.org/10.3390/w8040130

[22] Wang J., Wang Zh., Carolina L. et al.: Ultrasonics Sonochem., 2019, 55, 273. https://doi.org/10.1016/j.ultsonch.2019.01.017

[23] Kondratovych O., Koval I., Kyslenko V.: Chem. Chem. Technol., 2013, 7, 185. https://doi.org/10.23939/chcht07.02.185 [24] Ojha K., Mason T., O’Donnell C. et al.: Ultrasonics Sonochem., 2017, 34, 410.

https://doi.org/10.1016/j.ultsonch.2016.06.001

[25] Al-Hashimi A., Mason T., Joyce E. et al.: Environ. Sci.

Technol., 2015, 49, 11697. https://doi.org/10.1021/es5045437

[26] Romenskiy A., Kazakov V., Grin G.: Ultrazvuk v

Heterogennom Katalize. Severodonetsk 2006.

[27] Koval I.: Int. Symposium "The Environment and the Industry", 20-21 September 2018, 362.

https://doi.org/10.21698/simi.2018.fp43

[28] Shevchuk L., Strogan O., Koval I.: Chem. Chem. Technol., 2012, 6, 219. https://doi.org/10.23939/chcht06.02.219

[29] Koval I., Falyk T.:15 ${ }^{\text {th }}$ Int. Scientific-Practical Conf "Resources of Natural Waters in Carpathian Region" (Problems of protection and rational exploitation), Ukraine, Lviv 2016, 92.

[30] Dehghani M., Mahvi A., Jahed G. et al.: J. Zhejiang Univ. Sci., 2007, 7, 493. https://doi.org/10.1631/jzus.2007.B0493

[31] Suslick K. (Ed.): Ultrasound: Its Chemical, Physical, and Biological Effects. VCH Publishers, New York 1988.

[32] Koval I., KislenkoV., Shevchuk L. et al.: Chem. Chem. Technol., 2011, 5, 463.

Received: June 21, 2019 / Revised: September 30, 2019 / Accepted: December 03, 2019

\section{КОРЕЛЯЦІЯ МІЖ ДІАМЕТРОМ МІКРООРГАНІЗМІВ ТА ЕФЕКТИВНІСТЮ РУЙНУВАННЯ МІКРООРГАНІЗМІВ ЗА УМОВ ГАЗ/КАВІТАЦІЯ}

\begin{abstract}
Анотація. Виконано порівняння значеннь ефективних констант швидкості знищення мікроорганізмів $\left(k_{d}\right)$, залежно від діаметру клітин та природи газу, барботованого за умов кавітації. Ефективність руйнування клітин за Ar / US більша в 2-2,5 рази порівняно з Не / US, O2 / US та CO2 / US. Клітини дріжджів руйнуються швидше у порівнянні з бактеріяли $\left(k_{d}\right.$ (клітини дріжджів) $>k_{d}$ (кпітини бактерій)), щฺо пояснюється розміром клітини. Стійкість клітини за умов кавітації обернено пропориійна ї̈ діаметру. Враховуючи розміри клітин, отримані залежності $k_{d}=f\left(d_{\text {клітин }}\right)$ можуть бути успішно використані як еталон не тільки для якісного визначення, але й для очінювання ефективності кавітаційного оброблення води в присутності $\mathrm{O}_{2}, \mathrm{CO}_{2}$, $\mathrm{Ar}$ та $\mathrm{He}$.
\end{abstract}

Ключові слова: діаметр клітини, кавітаиія, газ, вода, мікроорганізм, руйнування. 